\title{
An Empirical Research on Corporate Venture Capital and Value Creation of Invested Enterprises
}

\author{
Fu Zheng \\ Business School \\ Sichuan University \\ Chengdu, China
}

\author{
Hongxing Wen \\ Business School \\ Sichuan University \\ Chengdu, China
}

\author{
Xuchu Wen \\ School of Management and Science \\ Chengdu University of Technology \\ Chengdu, China
}

\begin{abstract}
Corporate Venture Capital (CVC) can bring investment companies with financial and strategic value which can promote the value of invested enterprise. However, because of factors of opportunism and asymmetric information, CVC will hinder the value of invested enterprise. This paper uses the data of A-Shares Listed Companies of China during 2010 to 2014, the analysis results present, (1) The enterprises accepted investment from $\mathrm{CVC}$ create less value than the enterprises did not. (2) The enterprises accepted investment from venture investment organization which hold by CVC create less value than the enterprises accepted investment from venture investment organization which shared by CVC. (3) Under the hold of CVC, the proportion of the organization in the invested enterprise is proportional to the value of the invested enterprise.
\end{abstract}

Keywords-Corporate Venture Capital; value creation; Tobin's $q$

\section{INTRODUCTION}

Venture capital, also known as venture capital investment, refers to investing funds in the research and development field of high technology and products with the risk of failure. It aims to promote commercialization of new technological achievements as soon as possible (Cheng Siwei, 2005). According to the different investment subjects and the different sources of funds, venture capital contains four categories: Independent Venture Capital (IVC), Corporate Venture Capital (CVC), Government Venture Capital and Angel Investment. In China, the main components of venture capital are independent venture investment and corporate venture investment, the scale of government investment and angel investment is relatively small.

Corporate venture capital refers to the internal and external investment activities of non-financial enterprises with specific main business; the external investment is mainly for new enterprises, especially the equity investment for high and new technology enterprises. CVC first appeared in United States in 1960s, and then developed rapidly in various countries and became an important part of the world venture investment. CVC started in China in the 1990s, and it has developed rapidly. According to the "China Venture Capital Yearbook" in recent years, it shows that CVC has become one of the main components of China's venture capital.

\section{LITERATURE REVIEW}

In general, there is not much research on the creation of $\mathrm{CVC}$ and the value of the invested enterprise. Exiting studies on value creation of CVC mostly base on the perspective of investors, and the studies of the value of the invested enterprise mostly combine with $\mathrm{VC}$, rather than continue to study the value creation of CVC and the invested enterprises. So it is important to analyze relationship corporate venture capital and value creation of invested enterprise.

\section{A. CVC and the Promotion of the Value Creation of the Invested Enterprise}

1) CVC and the financial value creation of the enterprise: Although there are not many researches on the value created by CVC and the invested enterprises, the value created by CVC for the invested enterprises can not be erased. It is mainly divided into two categories: financial value and non - financial value (strategic value). Gompers and Lerner (1999)[1] find that enterprises invested by CVC are more likely to enter the IPO stage and are unlikely to be liquidated. In different investment rounds, those with CVC investment will get higher valuations than IVC investing enterprises. Woojin Lee (2001)[2] shows that the IPO with corporate investors got higher price and market value than IPO without corporate investors. This not only creates huge financial gains for investors, but also creates financial value for enterprises to be invested. Qiao Mingzhe (2017)[3] found that the IPO underpricing level of companies invested by CVC is significantly lower than that of other enterprises, 
and the IPO underpricing level of companies invested by CVC is significantly lower than that of invested by IVC only.

2) CVC and enterprise strategic value creation: An enterprise that gets CVC support be able to perform well in IPO. The CVC can provides more value added services for the invested enterprises, and these value-added services mainly create "strategic value" for the invested enterprises. Dodo $(2005)^{[4]}$ summarizes the five major value contribution of investors are : cooperation with mature market participants (companies that bring the reputation effect), business simu lation through the original order, have the right to use the distribution channels, R\&D support and the establishment of domestic or international business association. Lee $(2001)^{[5]}$ et al. believe that there are four kinds of resources which are very important for the invested enterprises. They are entrepreneurship, development and implementation strategies, technological capabilities and social capital. On the basis of historical observation, Dodo divided the CVC into four categories: large technology companies, non-technology companies, management consulting companies and growth oriented enterprises. These four types of companies can provide the above four types of needed resources for investment companies urgently.

\section{B. CVC and Hinder the Value Creation of the Invested Enterprise}

Although CVC activity is beneficial to both sides, but due to the information asymmetry and opportunism, the CVC activity faces the information dilemma in practice, which leads to the inability of the investors and invested enterprises to achieve the contract efficiently. On the one hand, when facing with corporate investors, venture enterprises often don't want to disclose their information, because once an investment company takes opportunistic behavior, their new technology or unique business mode will be stolen, and the invested enterprise will have nothing. Whether it is IVC or CVC, the venture will not consider investing before the enterprises disclosing its own information. At this time, it is convenient to get into the information dilemma. Dushnitsky (2004)[6] pointed out that if the products of investment enterprises and start-up enterprises are potential substituted, the possibility of forming investment relationship between both sides will be reduced, which also proves the above contradictions. This is also a major hindrance to the further development of CVC. Katila (2008)[7] pointed out that the invested enterprises need funds and operation resources from the mature enterprises. CVC investors may be encroaching on their interests due to the attraction of technology and other important resources of the start-ups. Sun Jian et al. (2010)[8] pointed out that in order to reduce the concern of start-ups in opportunism, investors are more likely to invest indirectly by participating venture capital organizations rather than holding venture capital organizations.

\section{RESEARCH DESIGN AND HYPOTHESES}

CVC usually has three ways: direct investment, holding venture capital organization and equity participation venture organization. Holding venture capital organizations and equity participation venture capital organizations can also be named indirect investment. Because it is difficult to discriminate the CVC direct investment, we will not study direct investment in this article. From the above literature review, we can see that CVC can bring two functions to enterprises, one is to promote the value of the invested enterprises, financial value and strategic value and the other one is to hinder the value creation of the invested enterprises. When the effect of CVC promoting value added for the enterprise is greater than the effect of hindering the value added, it will lead the value of CVC background enterprises is higher than those without CVC background. But when the effect of CVC promoting value added for the enterprise is less than the effect of hindering the value added, then it causes the value of CVC background enterprises less than those without CVC. Therefore, the first hypothesis shows as following.

H1: There is a difference in value creation between enterprises that accept CVC investment or not. There may be two of the following cases that need to be verified:

H11: The enterprise that accepts the CVC investment has better value creation than the enterprise that has not accepted the CVC investment.

H12: The enterprise that accepts the CVC investment has less value creation than the enterprise that has not accepted the CVC investment.

CVC mainly invests companies by participating in the venture capital organization and holding venture capital organization. If the CVC holds venture capital organizations, CVC is more capable of leading venture capital organizations. At the same time, CVC can bring more technical experiences, management experiences, and funds needed by the invested enterprise, such as a series of factors that can increase its value, but also the problems such as opportunis $m$ between CVC and enterpris e will be increased significantly. When CVC is in the holding of venture capital organizations, if the value it brings to invested enterprises is significantly greater than that hinder the value-added function caused by opportunism, the enterprises invested by the venture investment mechanism held by CVC is better than enterprises invested by venture capital organization shared by CVC in the value creation. If it is CVC brings promoting value-added function is significantly less than the value of opportunism obstacles, the enterprises invested by the venture investment mechanism held by CVC is worse than enterprises invested by venture capital organization shared by CVC in the value creation. The second hypothes is of this article is put forward.

$\mathrm{H} 2$ : There is a significant difference in value creation between enterprises invested by CVC hold ing venture capital organizations and enterprises invested by CVC invested venture capital organizations. There are two specific situations: 
$\mathrm{H} 21$ : The value creation of the enterprises invested by CVC holding venture capital organization is superior to the enterprises invested by CVC participating venture capital organization.

$\mathrm{H} 22$ : The value creation of the enterprises invested by CVC holding venture capital organization is worse than the enterprises invested by CVC participating venture capital organization.

When CVC control the venture capital investment organization, the proportion of venture capital organization in the invested enterprise will directly affect the affect the investment degree of CVC. With the increasing in the proportion of the venture capitalists in the invested enterprises, the two aspects of the role of CVC to promote and hinder value added are both increasing. If the increase in the value promotion brought by CVC is greater than the increase in the hindrance of opportunis $m$, then the proportion of venture capital organizations has a positive relationship to the value of enterprise. If the increase in the value promotion brought by CVC is smaller than the increase in the hindrance of opportunism, then the proportion of venture capital organizations has a negative relationship to the value of enterprise. So the third hypothesis of this article is put forward.

H3: The proportion of the shares of the CVC holding companies in the invested enterprises has a linear relationship with the value of the enterprise. It can be divided into two categories.

H31: The proportion of the company is positively to the value of the enterprise.

H32: The proportion of the company is negatively to the value of the enterprise.

Through the empirical study of some listed companies, this paper will demonstrate the above hypothesis with the help of the relevant data of A-Shares Listed companies in China.

\section{EMPIRICAL RESEARCH AND RESULT ANALYSES}

\section{A. Variable Selection}

Only third of the three hypotheses that need to be verified in this article need regression analysis. Therefore, the variables in this paper are only aimed at third hypotheses, and the selection methods are as follows:

Dependent variable: in the quantitative study of company value creation, Tobin's $Q$ value is usually used as a tool to measure the value creation of the company. Through the interpretation and study of Tobin's Q theory, we also think that it is feasible to use $\mathrm{Q}$ value to reflect the company's value creation ability. Therefore, in this paper we will select the Tobin's Q value, take the natural logarithm of it, and get LNTOBINQ as the dependent variable to reflect the value creation of CVC and enterprise.

Independent variable: the share of the CVC holding investment organization in the invested enterprise is the independent variable. If there are more than one CVC holding investment organization in the ten major shareholders of a listed company, the shares held by all of them will be the shares of CVC holding venture capital company. Therefore, in this paper we will select the share proportion of the invested enterprises of CVC holding investment organization, take the natural logarithm of it, and get LNPRO as the independent variable. And, in the analys is the argument is to remove the CVC percent stake as an independent variable. For example, $20 \%$ is a 20 natural logarithm, which is calculated by LN20.

\section{B. The Principle of Data Collection and Screening}

In this paper, the data of $913 \mathrm{~A}$-Shares Listed Companies of China during 2010-2014 years is collected as research samples. First of all, it should be determined whether the company received CVC investment, and the standard to judge is:

In the list of the top ten shareholders in its list, whether there is a "XX investment company, XX capital management company" or "XX company", if there is, further to determine whether the "XX investment company has CVC background through the search for relevant news and announcements or access to its official site. If there is, it will be recognized having an acceptance of CVC investment.

The second step is to judge that the CVC investment accepted by the company belongs to the CVC holding venture capital organization or the CVC participating ventu re capital organization. The standard to judge is: the first step to determine the "XX Investment Company has venture capital company background, and then find whether the first major shareholder of the "XX investment company" is a nonfinancial company based on non-venture capital business for the main business. If it is like that, it judged as CVC holding, if not judged as CVC sharing.

The third step is to calculate the share proportion of the CVC holding companies in the listed companies. If there are more than one CVC holding investment organization in the ten major shareholders of a listed company, the shares held by all of them will be the shares of CVC holding Venture Capital Company.

After excluding the data of incompletion, financial industry and real estate enterprises, we get data from 851 enterprises. Among them, 583 enterprises did not receive CVC investment, accounting for $68.43 \%$ of the total, and 269 received CVC investments, accounting for about $31.57 \%$. Among the 269 enterprises that accept CVC investment, there are 114 enterprises that invested by CVC holding venture capital organizations, accounting for $13.38 \%$ of the total investment. The number of enterprises who invested by CVC ventures is 155 , accounting for $18.19 \%$. The specific data are shown in "Table I": 
TABLE I. AMOUNTS AND PROPORTION DISTRIBUTION OF OBSERVATION VALUE

\begin{tabular}{|c|c|c|c|c|}
\hline & Freq. & NO CVC & $\begin{array}{c}\text { CVC } \\
\text { HOLDING }\end{array}$ & $\begin{array}{c}\text { CVC } \\
\text { SHARING }\end{array}$ \\
\hline Amounts & 851 & 583 & 113 & 155 \\
\hline Proportion & $100 \%$ & $68.43 \%$ & $13.38 \%$ & $18.19 \%$ \\
\hline
\end{tabular}

The company's Tobin $Q$ value comes from the database of CSMAR. The $\mathrm{Q}$ values of each company in the database have four different values of $\mathrm{A}, \mathrm{B}, \mathrm{C}$ and $\mathrm{D}$ because of the different computing methods. The specific calculation method is:

Market value A=equity market value + net debt market value, in which non tradable stock. Market value is replaced by net assets

Market value $\mathrm{B}=$ equity market value + net debt market value, in which the market value of non-tradable stock is replaced by the circulation share price

Tobin's $Q$ value $A=$ market value $A$ / final totalasset

Tobin's $\mathrm{Q}$ value $\mathrm{B}=$ market value $\mathrm{A}$ / (total assets - net worth of intangible assets)

Tobin's $\mathrm{Q}$ value $\mathrm{C}=$ market value $\mathrm{B} /$ final total as set

Tobin's $\mathrm{Q}$ value $\mathrm{D}=$ market value $\mathrm{B} /$ (total assets - net worth of intangible assets)

The basic idea of Tobin's Q theory is to reflect the ratio between the market value of an enterprise's and the cost of resetting. Therefore, the closer the molecule is to the market value, the more reliable it is. If the market value of tradable shares is replaced by the share price of tradable shares, the Tobin's $Q$ value will be higher. Therefore, it is more consistent with the Tobin's Q theory to replace the value of non-circulation shares with the value of the net assets instead of the value of the non-circulation share. At the same time, intangible assets are also part of the assets of a company, which Resetting also costs a lot of replacement costs. Therefore, the use of "ending total assets" is relatively reliable. Based on the above judgment, this paper selects the A value of Tobin' $Q$ as the dependent variable. Because the value creation effect of venture capital requires a process, this article intercepts the Tobin's Q value of each company in the year of 2016 .

\section{Empirical Results}

1) Descriptive statistics of $Q$ value: "Table II" shows the Tobin's Q value comparison after 851 companies are divided into accepting CVC and unaccepting the CVC two groups. It can be seen that, whether the mean value of $\mathrm{Q}$, the maximum value, the minimum value, the receiving group are lower than the unaccepted group, but the variance is higher. Through further analysis, it is found that the amount of $\mathrm{Q}$ value worth more than 2 of the CVC investment companies group is 168 , worth more than 3 is 104 , accounting for $62.45 \%$ and $38.66 \%$ of the number of enterprises in the receiving group, respectively. The proportion of the number of enterprises in the receiving group is $62.45 \%$ and $38.66 \%$, respectively. The amount of
$Q$ value worth more than 2 of the non-CVC investment companies group is 418 and worth more than 3 is 268 . The proportion of unreceived groups was $71.58 \%$ and $49.06 \%$, respectively. From the above analysis, it has reflected that the $\mathrm{Q}$ value of the enterprise receiving CVC investment is less than that of the unaccepted CVC investment enterprise. This is just the second case in our first hypothesis. It shows that CVC's role in creating value for investment is less than the effect of hinder value added factors.

TABLE II. Q VALUE COMPARISON FOR ENTERPRISES

\begin{tabular}{|c|c|c|}
\hline & $\begin{array}{c}\text { Company accepting CVC } \\
\text { investment }\end{array}$ & $\begin{array}{c}\text { Company unaccepting CVC } \\
\text { investment }\end{array}$ \\
\hline Amounts & 269 & 583 \\
\hline Average & 3.03 & 3.61 \\
\hline Minimum & 0.26 & 0.75 \\
\hline Maximum & 15.23 & 20.91 \\
\hline Variance & 4.02 & 3.90 \\
\hline
\end{tabular}

"Table III" reflects that all 268 companies with CVC investment background are divided into accepting investment of CVC holding venture capital organizations and CVC participating venture capital organizations two groups. It can be seen that although the maximum value of the CVC holding group is superior to the CVC participating group, the mean and minimum value are all smaller than that of the participating group, and the variance is basically equal. Through further analysis, it is found that the amount of Q value worth more than 2 of the CVC holding venture capital organizations group is 70 , and worth more than 3 is 40 , accounting for $61.95 \%$ and $35.95 \%$ respectively. The amount of $\mathrm{Q}$ value worth more than 2 of the CVC participating venture capital organizations group is 97 and more than 3 is 63 , accounting for $62.58 \%$ and $40.65 \%$, respectively. From the above analysis, it reflect that the Q value of CVC holding venture capital organizations is worse than that of CVC participating venture capital organizations. This is just the second case of our second hypothesis. CVC's role in promoting value added to the invested enterprises is significantly less than that which hinders the value added factors of the invested enterprises, when under the holding venture capital organization

TABLE III. Q VALUE COMPARISON OF VC BACKGROUND ENTERPRISES

\begin{tabular}{ccc}
\hline & CVC holding & CVC participating \\
\hline Amounts & 113 & 155 \\
\hline Average & 2.87 & 3.12 \\
\hline Minimum & 0.26 & 0.52 \\
\hline Maximum & 15.23 & 10.67 \\
\hline Variance & 1.98 & 2.0 \\
\hline
\end{tabular}

2) The correlation analysis of the proportion of CVC holding companies in invested enterprises and the $Q$ value of the enterprises, and the results of the regression: This paper uses spss 21 as a statistical data analysis tool. The correlation between the proportion of CVC holding companies in the enterprise and the $\mathrm{Q}$ value of the enterprise is analyzed. We use LNTOBINQ as an enterprise Q value, and use LNPRO. as the corresponding proportion, Q value as an enterprise with LNTOBINQ, using LNPRO. The 
research sample for the corresponding proportion. The research sample is 113 enterprises invested by the CVC holding venture after eliminating financial and real estate. The analysis has passed the significance test, the correlation coefficient is 0.192 .

There is a significant positive correlation between the Q value of the enterprise and the shares of CVC investors in the company. The higher share of CVC investors, the greater the $Q$ value of the enterprise. It is indicated that in the case of the CVC holding venture, with the increasing of the CVC holding company's share in the start-up company, the growth rate that CVC brings to the business to increase value is greater than that of the increasing value of the impede value added of the invested enterprise. It just validates the first case in hypothesis 3 . A regression equation can be used to express the relationship as following.

LNTOBINQ=0.68+0.13LNPRO.

\section{T $(6.263$ 2.064)}

Sig. (0.000 0.041)

\section{Result Analysis}

1) CVC value creation mechanism based on the perspective of the invested enterprise: The corporate venture capital (CVC) can provide the funds, a mature operation and management experience needed by the invested enterprise. Even a business partnership can be established with the invested enterprise. Once CVC has invested in an enterprise, it faces CVC's possible opportunistic behavior and a strategic service crisis for CVC. The existence of this crisis will impede the value creation of the invested enterprise. The effect of this kind of hindrance is greater than the effect of CVC on the value added of the invested enterprise. Therefore, in the value added performance, the value added of the enterprise with CVC backg round is less than that of the enterprise without the CVC background.

2) Analysis of controlling factors: CVC usually has two aspects of investing in a venture: one is the financial objective, what can get a lot of direct financial returns through investment; other one is the strategic purpose. This goal is usually through investing start businesses to learn and acquire the core technology at present, or to establish partnerships with the invested enterprises, so as to achieve the goal of resource complementarity. Based on the large amount of capital and late mature management concept that CVC can bring, what is usually considered for the invested enterprise is how to protect core technology after successful CVC investment. Under the situation of holding venture capital organizations, CVC is more able to manipulate the organization's behavior, so it will have greater chance to take opportunistic behavior, resulting in the investment enterprise's value being infringed. Therefore, the invested enterprise usually choose the CVC participating venture capital organizations to get the investment rather than the CVC holding venture.
After the CVC holding company, the cost of capital invested by CVC will be greatly increased with the increase in the proportion of the organization in the invested enterprise, and more governance costs will be spent on the governance of the invested enterprise. This will undoubtedly greatly increase the enterprise value, and the growth rate of this kind of value will be greater than that of the hinder value added factor. As a result of the increase in the proportion of venture capital organizations in the invested enterprises, the value of the invested enterprise is also increasing in the positive direction.

\section{CONCLUSION}

The above analyses show following conclusions: (1) The enterprise value creation that accepts the corporate venture capital investment is less than the enterprise that does not accept the corporate venture capital. (2) The company invested by a CVC holding venture capital organization create less value than the company which invested by the CVC participating venture capital organization. (3) Under the hold of CVC, the proportion of the organization in the invested enterprise is proportional to the value of the invested enterprise.

For the invested enterprise, (1) Because of the lack of funds, they need to introduce investment during the start-up period, invested enterprise should considering the introduction of independent venture capital firstly, considering venture investment organization of CVC participation secondly, considering the venture capital organization of CVC holding finally. (2) If the invested enterprise introduced the venture capital organization of CVC holding, then the invested enterprise can consider to increase the shares of the capital organization of CVC holding under the condition of not affecting its holding, to make this investment project occupies an important place in investments that made by investors, and the invested enterprise can obtain more high quality value-added services.

\section{REFERENCES}

[1] Paul Gompers, Josh Lerner. The vent ure capital cycle[M]. Cambridge, MA\& London: MIT Press, 2000.

[2] Woojin Lee. An analysis of US major corporate and venture Funds[R].Paper presented to ET RI, [EB/OL]. http://ftp. cob .sjsu.edu, 2001,10 .

[3] Qiao Mingzhe, Zhang Yuli, Ling Yu, Li Jinliang. How does the vent ure capital affect the IPO underpricing of the invested enterprise? -- Evidence from Shenzhen gem, [J]. Nankai management review, 2017: 167-180.

[4] Dodo Zu KnyPhause-AufseB, "Corporate venture capital: who adds value?" [J], Venture Capital, 2005, (7): 23-49.

[5] Choonwoo Lee, Kyung mook Lee and Johannes M. Pennings, "Internal capabilities, external networks, and Performance: a study on technology-based ventures" [J], Strategic Management Joumal, 2001, (22): 615-640.

[6] Dushnitsky G, Lenox, "When do incumbents learn from entrepreneurial ventures? Corporate venture capital and investing firm innovation rates", [J], Research Policy, 2005, (34): 615-639.

[7] Katila, R. Rosenberger, J.D., Eisenhardt, K. M., "Swimming with Sharks: Technology Ventures, Defense Mechanisms and Corporate 
Relationships,” [J],. Administrative Science Quarterly, 2008. (53):295-332.

[8] Sun Jian, Bai Quanmin., "An empirical study of the impact of corporate venture capital (CVC) on business value in China: Based on the perspective of CVC investors," [J]. Journal of Central University of Finance and Economics, 2010, (9):62-66.

[9] Chinese Institute of certified public accountants. Accounting [M]. Beijing: China financial and economic press, 2013.

[10] Liang Xiaoyan,"Value creation mechanism and information dilemma of corporate venture investment (CVC) ",[D],Hefei: University of Science \&amp; Technology China, 2007.

[11] Liang Xiaoyan, Mi Zhongchun, Wang Hongyu, Ye Yuexiang, "The information dilemma and evolutionary game analysis between the venture investors and the invested entrepreneurs", [J]. science and technology management, 2006, (9):155-159.

[12] Yu Bo. Research on venture capital and enterprise value creation based on China's theory and empirical analysis [D]. Hangzhou: Zhejiang University, 2014. 